\title{
Evaluation of biomass yield and nutritional quality of oats-vetch mixtures at different harvesting stage under residual moisture in Fogera District, Ethiopia
}

\author{
Eshetie Alemu Molla ${ }^{1}$, Berhanu Alemu Wondimagegn ${ }^{1}$ and Yeshambel Mekuriaw Chekol ${ }^{*}$
}

\begin{abstract}
Background: This study was conducted in Fogera District, north western Ethiopia, to evaluate the effect of harvesting stages on biomass yield and nutritive value of oat-vetch mixtures under residual moisture. The experimental plots were prepared thoroughly by plowing the land before sowing. The experiment was conducted using randomized complete block design in a factorial arrangement having two factors with three replications. The first factor, factor A, comprises a four combinations of two forage species (oats and vetches) having two varieties each. The two oats varieties used were $\mathrm{Cl}-8237$ and $\mathrm{Cl}-8251$, represented as $\left(\mathrm{O}_{1}\right)$ and $\left(\mathrm{O}_{2}\right)$ and the two vetch varieties, Vicia villosa and Vicia dasycarpa, represented as $\mathrm{V} 1$ and $\mathrm{V} 2$, respectively. The second factor, harvesting stage, had three levels which follows the three physiological stages of oat varieties as flag leaf stage $\left(\mathrm{HS}_{1}\right)$, milk stage $\left(\mathrm{HS}_{2}\right)$ and dough stage $\left(\mathrm{HS}_{3}\right)$ in the mixtures. Agronomic performance and forage biomass yield were recorded. Chemical compositions of the forage such as crude protein (CP), ash, neutral detergent fiber, acid detergent fiber, acid detergent lignin, hemicellulose and cellulose were determined. Data were analyzed with general linear model procedure of SAS (version 9.1; 2008).
\end{abstract}

Results: Results indicated that harvesting stages significantly $(P<0.001)$ affected most of the agronomic parameters in oats varieties, whereas plant height and number of branches were significant $(P<0.05)$ in vetch varieties. Significantly higher $(P<0.001)$ plant height, number of leaves per plant and leaf to stem ratio) were obtained in variety oats Cl-8237. Dry matter yield (DMY) and chemical compositions of the forage were significantly affected $(P<0.001)$ by harvesting stages. More vigor and higher number of branches were recorded in V. villosa, but higher plant height was obtained in $V$. dasycarpa. The highest mean DMY (4.99 t/ha) and CP yield ( $0.81 \mathrm{t} / \mathrm{ha})$ were recorded at harvesting stage two $\left(\mathrm{HS}_{2}\right)$. However, the lowest DMY (3.42 t/ha) was obtained at harvesting stage one. Relatively, the optimum DMY ( $6.16 \mathrm{t} / \mathrm{ha}$ ) with maximum CP yield ( $0.92 \mathrm{t} / \mathrm{ha}$ ) was recorded from mixture of $\mathrm{Cl}-8237+\mathrm{V}$. villosa at harvesting stage two. The fiber components were increased with advanced stage of growth, but CP and ash contents were decreased as the age of the plant matures.

Conclusions: Production of $\mathrm{Cl}-8237+$ V . villosa mixture harvested at harvesting stage two would be more beneficial to produce optimum yield and nutritive value and could be recommended in the study area.

Keywords: Chemical composition, Harvesting stage, Legume and grass, Mixture, Residual moisture

\footnotetext{
*Correspondence: yeshambel166@gmail.com

2 Department of Animal Production and Technology, Bahir Dar University,

P.O. Box 5501, Bahir Dar, Ethiopia

Full list of author information is available at the end of the article
} 


\section{Introduction}

Ethiopia has a huge livestock population with an estimated 57.83 million cattle, 28.89 million sheep, 29.70 million goats, 7.88 million donkeys, 2.08 million horses, 0.41 million mules and 1.23 million camels [1]. The sector plays an important socioeconomic role in food security, generating additional cash income at household levels and also provides export earnings [2]. However, the contribution is still low compared to the potentials expected from the sector. Many factors are constraining the development of this sector, among which feed scarcity in terms of quantity and quality are the major ones in almost all parts of the country [3].

Development interventions encouraging adoption of forage legumes will achieve a double advantage of enhancing the livelihoods of rural households and at the same time prevent or mitigate land degradation [4]. Therefore, improved forage production and devising strategies to increase their productivity are mandatory in order to improve animal production and productivity in the country. Growing of forages after harvesting of food crops using residual moisture is assumed to be the best strategy to alleviate land scarcity problems. Moreover, this system is becoming increasingly considered to improve the soil health. Harvesting time of the associated forage crops, however, poses many problems to the farmers to manage the mixtures [5]. It is also reported that grasses are sown mixed with legumes to be used as a climbing frame for the legumes and to increase the bulk of feed produced [6]. The productivity of oats and vetch mixtures are known to be superior to either of the pure stands in yield and quality [7]. Vetch is the most important and widely used annual forage legume in the highland farming systems of the country under different production strategies as it grows well on different soil types [8]. Oats is also a well-adapted fodder crop used as energy source for livestock [9]. In the mixtures, oats can provide support for climbing vetch, improve light interception through the canopy, facilitate mechanical harvesting, and reduce rotting of vetch hay. However, limited information is available on the performance of oats/vetch mixture grown using residual moisture as affected by harvesting stage in the Fogera plain. Therefore, the objectives of the study were to evaluate agronomic performance and chemical composition of oats/vetch mixtures at different harvesting stages.

\section{Materials and methods}

\section{Description of the study area}

The study was conducted in Fogera district Northwest Ethiopia located $625 \mathrm{~km}$ North West of Addis Ababa. The geographical location is between $11^{\circ} 58^{\prime} \mathrm{N}$ latitude and $37^{\circ} 41^{\prime} \mathrm{E}$ longitude. The climate of the area is characterized by warm temperature with unimodal rainfall type. It is predominantly classified as moist Woina-dega in agroecology. The mean minimum and maximum temperatures are $11.48{ }^{\circ} \mathrm{C}$ and $27.3{ }^{\circ} \mathrm{C}$, respectively. The annual rainfall of the area ranged from 1103 to $2400 \mathrm{~mm}$ with the main rainy season usually extending from May to September. The topography of the district comprises $76 \%$ flatlands, $11 \%$ mountains and hills, and $13 \%$ valley bottom lands [10]. The dominant soil type is black clay soil $(65 \%)$ and the rest $20 \%, 12 \%$, and $3 \%$ are brown, red and gray, respectively. In terms of land use pattern, an estimated $64 \%$ of the area is cultivated with annual and perennial crops, while the area under grazing and browsing, forests and shrubs, settlements and wastelands account for about $15,1.8,8$ and $11.2 \%$, respectively. The total area of the District is estimated to be 117,414 ha [11]

\section{Land preparation and experimental design}

The experimental plots were prepared thoroughly by plowing the land before sowing. The experiment was conducted using randomized complete block design (RCBD) in a factorial arrangement with three replications. The two factors were the four mixtures (factor A) of the two oat varieties $\left(\mathrm{O}_{1}\right.$ and $\left.\mathrm{O}_{2}\right)$ and the two vetch varieties $\left(\mathrm{V}_{1}\right.$ and $\left.\mathrm{V}_{2}\right)$ and the three harvesting stages (factor B) (flag leaf stage: HS1), (milk stage: HS2) and (dough stage: HS3). So the experiment had a $4 \times 3$ factorial combinations with three replications. The oats varieties used were CI-8237 and CI-8251 and vetch species were Vicia villosa and Vicia dasycarpa. The seed proportions were oats $25 \%+75 \%$ vetch which is based on the recommended sole seed rates of 80 and $25 \mathrm{~kg} / \mathrm{ha}$ for oats and vetch, respectively. The plot size was $2 \mathrm{~m} \times 3 \mathrm{~m}$, and the spacing between replications and plots was 1.5 and $0.5 \mathrm{~m}$, respectively [12]. Animal manure was applied in equal amount on all plots.

\section{Sampling procedures and data collection}

The plant height for each species was determined by measuring the height of ten randomly selected plants from ground level to the tip of the plant, and their average was recorded [12]. Number of leaves per plant for oats and number of branches per plant for vetch were recorded at each harvesting stage by taking 10 plants from each plot. Leaf to stem ratios for oats at each harvesting stage was measured and calculated for each plot on dry matter basis. For measuring plant height and DM accumulation over the growing period, ten plants of each species were harvested from ground level from each plot every 20 days interval starting from the 20th day of plant growth [13]. Harvesting for biomass yield and nutritional analysis were taken at three different stages viz., flag leaf stage $\left(\mathrm{HS}_{1}\right)$, milk stage $\left(\mathrm{HS}_{2}\right)$ and dough stage 
$\left(\mathrm{HS}_{3}\right)$ following the physiological stages of oats. Total fresh weight of mixtures in each plot was weighed from samples taken from an area of a $1 \mathrm{~m} \times 1 \mathrm{~m}$ quadrate to estimate fresh biomass yield. The samples were chopped and thoroughly mixed. A $200 \mathrm{~g}$ sub sample was taken and dried in a forced draft oven at a temperature of $105{ }^{\circ} \mathrm{C}$ overnight for dry matter yield determination.

\section{Chemical analysis}

The total ash and crude protein contents were determined according to the procedures described by [14]. Neutral detergent fiber (NDF), acid detergent fiber (ADF) and acid detergent lignin (ADL) were analyzed following the procedures described by [15]. The crude protein yield (CPY) $(\mathrm{t} / \mathrm{ha}$ ) was determined by multiplying DMY by $\mathrm{CP}$ percentage.

\section{Data analysis}

The data were analyzed using the general linear model (GLM) procedure of [16]. Mean treatment comparisons were done using Duncan's Multiple Range Test (DMRT) for variables in which F-values declared a significant difference and differences were considered statistically significant at $5 \%$ level.

The statistical model used was: $Y_{i j k}=\mu+r_{i}+A_{j}+B_{k}+(A B)_{j k}+e_{i j k}$, where $Y_{i j k}$ is the response variable; $\mu$, over all mean; $r_{i}$ is the $i$ th replication effect; $A_{j}$ is the $j$ th factor effect (harvesting stage 1-3); $B_{k}$ is the $k$ th factor effect (variety combinations $1-4) ;(A B)_{j k}$ is the $j k$ th interaction effect (harvesting stage $\times$ Variety combinations); $e_{i j k}$ is the random error.

\section{Results and discussion}

Agronomic performance of oat and vetch varieties Plant height of oat varieties and vetch species

Plant height in oats was affected by both harvesting stages and varieties (Table 1). However, their interactions were not significant $(P>0.05)$. Plant height of oats at $\mathrm{HS}_{2}$ and $\mathrm{HS}_{3}$ were significantly higher than $\mathrm{HS}_{1}$, but statistically significant difference $(P>0.05)$ was not observed between $\mathrm{HS}_{2}$ and $\mathrm{HS}_{3}$. The current study was supported by Shoaib et al. [17] who indicated that harvesting stage is the most important factors which affect plant physiology in terms of plant height. But Berhanu et al. [18] reported higher values $(111.5-118 \mathrm{~cm})$ at the 80th day of harvesting compared to the results of the current study. This higher variation in plant height might be attributed by factors such as season and soil type which can positively affect this character. On the other hand, plant height was significantly $(P<0.001)$ affected by varieties of oats with higher values recorded for CI-8237 compared to CI-8251. The variation in plant height may be attributed to variation in genetic
Table 1 Plant height $(\mathrm{cm})$ for oats varieties and vetch species

\begin{tabular}{llllll}
\hline Species & Variety/species & \multicolumn{4}{l}{ Harvesting stages } \\
\cline { 3 - 6 } & & HS $_{\mathbf{1}}$ & $\mathbf{H S}_{\mathbf{2}}$ & $\mathbf{H S}_{\mathbf{3}}$ & Mean \\
\hline Oats & Oats CI-8237 & $66.03^{\mathrm{b}}$ & $71.8^{\mathrm{a}}$ & $71.06^{\mathrm{a}}$ & $69.63^{\mathrm{a}}$ \\
& Oats CI-8251 & $60.66^{\mathrm{c}}$ & $66.3^{\mathrm{b}}$ & $66.96^{\mathrm{b}}$ & $64.64^{\mathrm{b}}$ \\
& Mean & $63.35^{\mathrm{b}}$ & $69.05^{\mathrm{a}}$ & $69.02^{\mathrm{a}}$ & 67.14 \\
& SE & 2.096 & & & \\
& CV & 3.122 & & & \\
\multirow{5}{*}{ Vetch } & P value (varieties) & 0.0005 & & & \\
& Vicia villosa & $66.1^{\mathrm{c}}$ & $74.93^{\mathrm{ab}}$ & $72.6^{\mathrm{ab}}$ & $71.21^{\mathrm{b}}$ \\
& Vicia dasycarpa & $70.73^{\mathrm{b}}$ & $76.66^{\mathrm{a}}$ & $74.86^{\mathrm{ab}}$ & $74.08^{\mathrm{a}}$ \\
& Mean & $68.41^{\mathrm{b}}$ & $75.8^{\mathrm{a}}$ & $73.73^{\mathrm{a}}$ & 72.65 \\
& SE & 2.454 & & & \\
& CV & 3.378 & & & \\
& P value (species) & 0.0321 & & &
\end{tabular}

SE standard error, $C V$ coefficient of variation, $H S$ harvesting stage

a-c Variety/species means values having same superscript within a row are not significantly different $(P>0.05)$

make-up, soil type, season and adaptability of the varieties to different environmental conditions.

Harvesting stages and species also had significant effect on vetch plant height but interaction of the two factors was not significant. The lowest vetch plant height was recorded at $\mathrm{HS}_{1}$, but differences were not observed between $\mathrm{HS}_{2}$ and $\mathrm{HS}_{3}$. Higher plant height was recorded for $V$. dasycarpa as compared to $V$. villosa. The variation in plant height between the two vetch species might be due to their species differences and growth habit. The current result agrees with the finding of Gezahegn et al. [19] who reported taller plant height for $V$. dasycarpa followed by V. villosa and Vicia atropurpurea. Similarly, Desalegn and Hassen [20] stated that Vicia sativa was the shortest vetch species having an average height of $81 \mathrm{~cm}$ and $V$. dasycarpa was the tallest $(130 \mathrm{~cm})$ followed by $V$. villosa and $V$. atropurpurea $(126 \mathrm{~cm}$ and $115 \mathrm{~cm})$, respectively, using monoculture cultivation.

\section{Number of leaves per plant and leaf to stem ratio for oat varieties}

Significant variation was observed in number of leaves per plant by varietal mixture and harvesting stage as main effects, but no significant difference was observed due to their interactions (Table 2). In this case, the highest number of leaves per tiller (5.03) was recorded at $\mathrm{HS}_{3}$ and the least at $\mathrm{HS}_{1}$ (4.38). Oats variety $\mathrm{CI}-8237$ produced the highest $(P<0.001)$ number of leaves per tiller (5.21) compared to oats variety CI-8251 (4.34) (Table 2). 
Table 2 Number of leaves per plant and leaf to stem ratio for oats varieties at different harvesting stages

\begin{tabular}{|c|c|c|c|c|c|}
\hline \multirow[t]{2}{*}{ Parameters } & \multirow[t]{2}{*}{ Oats varieties } & \multicolumn{4}{|c|}{ Harvesting stages } \\
\hline & & $\mathrm{HS}_{1}$ & $\mathrm{HS}_{2}$ & $\mathrm{HS}_{3}$ & Mean \\
\hline \multirow{6}{*}{$\begin{array}{l}\text { Number of leaves per } \\
\text { tiller }\end{array}$} & Oats Cl-8237 & $4.67^{b}$ & $5.43^{\mathrm{a}}$ & $5.53^{\mathrm{a}}$ & $5.21^{\mathrm{a}}$ \\
\hline & Oats Cl-8251 & $4.1^{c}$ & $4.4^{\mathrm{bc}}$ & $4.53^{b}$ & $4.34^{b}$ \\
\hline & Mean & $4.38^{b}$ & $4.92^{\mathrm{a}}$ & $5.03^{\mathrm{a}}$ & 4.78 \\
\hline & SE & 0.167 & & & \\
\hline & $C V$ & 3.495 & & & \\
\hline & $P$ value (varieties) & 0.0001 & & & \\
\hline \multirow[t]{6}{*}{ Leaf to stem ratio } & Oats CI-8237 & $1.07^{\mathrm{a}}$ & $0.94^{c}$ & $0.73^{e}$ & $0.91^{\mathrm{a}}$ \\
\hline & Oats Cl-8251 & $0.99^{b}$ & $0.89^{d}$ & $0.71^{\mathrm{e}}$ & $0.87^{b}$ \\
\hline & Mean & $1.03^{\mathrm{a}}$ & $0.92^{b}$ & $0.72^{c}$ & 0.89 \\
\hline & SE & 0.018 & & & \\
\hline & $C V$ & 2.075 & & & \\
\hline & $P$ value (varieties) & 0.0004 & & & \\
\hline
\end{tabular}

$S E$ standard error, $C V$ coefficient of variation, $H S$ harvesting stage

a-e Variety means values having same superscript within a row are not significantly different $(P>0.05)$

The current study was in line with Berhanu et al. [18] who reported the highest and lowest number of leaves per plant in oats to be 5.15 and 4.58 , respectively.

Leaf to stem ratio was affected by the main and interaction effects. Based on this result, the highest leaf to stem ratio was recorded at $\mathrm{HS}_{1}$ (1.03) followed by $\mathrm{HS}_{2}(0.92)$ and the lowest value was obtained at $\mathrm{HS}_{3}(0.72)$. The current result indicated that leaf to stem ratio decreased with increasing age which agrees with the work of Berhanu et al. [18] who reported the highest leaf to stem ratio at $\mathrm{HS}_{1}$. The reason might be the loss of leaves as the plants become more matured. The results of the current study indicated that leaf to stem ratio in both oats varieties decreased with the delay in harvesting stages. The higher $(P<0.001)$ leaf to stem ratio was recorded in CI-8237 compared to CI-8251 (Table 2).

\section{Number of branches per plant for vetch species}

A number of branches per plant in vetch were affected by both harvesting stages and species as shown in Table 3. An increasing number of branches per plant were recorded with harvesting stage. As age of the plant is increasing, there is possibility for emergence of new branches.

The current study showed higher number of branches per plant at $\mathrm{HS}_{3}$. But $\mathrm{HS}_{2}$ showed similar values with $\mathrm{HS}_{1}$ and $\mathrm{HS}_{3}$ (Table 3). On the other hand, V. villosa had higher number of branches than $V$. dasycarpa (Table 3 ). The current result was supported by Gezahegn et al. [19] who reported that $V$. dasycarpa and $V$. villosa giving the highest branches per plant.
Table 3 Number of branches/vetch plant in oat-vetch mixtures at different cutting times

\begin{tabular}{lllll}
\hline Species & \multicolumn{4}{l}{ Harvesting stages } \\
\cline { 2 - 5 } & $\mathbf{H S}_{\mathbf{1}}$ & $\mathbf{H S}_{\mathbf{2}}$ & $\mathbf{H S}_{\mathbf{3}}$ & Mean \\
\hline Vicia villosa & $12.6^{\mathrm{bc}}$ & $13.43^{\mathrm{ab}}$ & $14.57^{\mathrm{a}}$ & $13.53^{\mathrm{a}}$ \\
Vicia dasycarpa & $10.57^{\mathrm{d}}$ & $11.27^{\mathrm{cd}}$ & $12.47^{\mathrm{bc}}$ & $11.43^{\mathrm{b}}$ \\
Mean & $11.58^{\mathrm{b}}$ & $12.35^{\mathrm{ab}}$ & $13.52^{\mathrm{a}}$ & 12.48 \\
SE & 0.98 & & & \\
CV & 7.84 & & & \\
$P$ value (species) & 0.0011 & & & \\
\hline
\end{tabular}

SE standard error, $C V$ coefficient of variation, $H S$ harvesting stage

a-d Species means values having same superscript within a row are not significantly different $(P>0.05)$

\section{Changes in dry matter accumulation and plant height of oats varieties}

DM accumulation and plant height of oats varieties are presented in Table 4. The result showed that the increase in DM accumulation and growth in height during the twentieth and fortieth day of sampling was generally low compared to the rest of the sampling stages. Significant differences were not observed between the two oats varieties during the initial stage of growth. The rate of DM accumulation and growth in height were not significant at the 20th and the 40th sampling days. Change of DM accumulation had no significant variation between the two oats varieties at the 60th sampling days. However, after 40th day, the rate of DM accumulation and growth in height was increased with faster rates in both oats varieties. The result was in agreement with Negash et al. [21] who stated that plant height has a main contribution in green fodder and dry matter yield.

The current result indicated that plant height at 60th, 80th and 100th day of growth was higher in oat variety CI-8237 compared to CI-8251. On the other hand, higher DM accumulation was obtained at the 80th and the 100th day of growth for oats variety CI-8237 compared to CI-8251 (Table 4). The result of the current study was found to be in line with Berhanu et al. [18] who reported similar values of dry matter accumulation and plant height in similar oat-vetch mixed experiments.

\section{Changes in dry matter accumulation and plant height of vetch species}

In the current study, DM accumulation and plant height were similar between the two vetch varieties during the early stages of vegetative growth, except DM accumulation at the 20th sampling day (Table 5). With regard to DM accumulation, significant $(P<0.05)$ variation was observed between the two vetch varieties at the 20th, 
Table 4 Dry matter accumulation and plant height of oats varieties at different growth stages

\begin{tabular}{|c|c|c|c|c|c|c|c|c|c|c|}
\hline \multirow[t]{3}{*}{ Variety } & \multicolumn{5}{|c|}{ Plant height (cm) } & \multicolumn{5}{|c|}{ Dry matter accumulation (g/10 plants) } \\
\hline & \multicolumn{5}{|c|}{ Cutting days after sowing } & \multicolumn{5}{|c|}{ Cutting days after sowing } \\
\hline & 20 & 40 & 60 & 80 & 100 & 20 & 40 & 60 & 80 & 100 \\
\hline Oats Cl-8237 & 12.98 & 25.55 & $45.92^{\mathrm{a}}$ & $67.18^{\mathrm{a}}$ & $71.80^{\mathrm{a}}$ & 1.21 & 10.50 & 31.62 & $50.24^{\mathrm{a}}$ & $52.37^{\mathrm{a}}$ \\
\hline Oats Cl-8251 & 13.06 & 24.72 & $39.83^{b}$ & $61.51^{b}$ & $66.44^{b}$ & 1.22 & 10.48 & 30.68 & $48.48^{b}$ & $49.98^{b}$ \\
\hline Mean & 13.02 & 25.13 & 42.88 & 64.35 & 69.12 & 1.22 & 10.49 & 31.15 & 49.36 & 51.17 \\
\hline SE & 1.95 & 2.31 & 6.16 & 6.10 & 6.92 & 0.18 & 1.19 & 2.08 & 1.96 & 1.80 \\
\hline CV & 14.95 & 9.20 & 14.37 & 9.48 & 10.01 & 14.52 & 11.30 & 6.68 & 3.97 & 3.52 \\
\hline$P$ value (varieties) & 0.9054 & 0.2883 & 0.0059 & 0.0091 & 0.0272 & 0.851 & 0.8666 & 0.1884 & 0.0113 & 0.0004 \\
\hline
\end{tabular}

SE standard error, CV coefficient of variation

$\mathrm{a}, \mathrm{b}$ Variety means with different letters in column are significantly different

Table 5 Dry matter accumulation and plant height of vetch species at different growth stages

\begin{tabular}{|c|c|c|c|c|c|c|c|c|c|c|}
\hline \multirow[t]{3}{*}{ Species } & \multicolumn{5}{|c|}{ Plant height $(\mathrm{cm})$} & \multicolumn{5}{|c|}{ Dry matter accumulation (g/10 plants) } \\
\hline & \multicolumn{5}{|c|}{ Cutting days after sowing } & \multicolumn{5}{|c|}{ Cutting days after sowing } \\
\hline & 20 & 40 & 60 & 80 & 100 & 20 & 40 & 60 & 80 & 100 \\
\hline Vicia villosa & 6.79 & 18.81 & 43.47 & $67.18^{b}$ & 73.21 & $1.03^{b}$ & 8.89 & 19.18 & $40.96^{\mathrm{a}}$ & $44.89^{\mathrm{a}}$ \\
\hline Vicia dasycarpa & 7.28 & 19.55 & 44.43 & $73.32^{\mathrm{a}}$ & 75.08 & $1.16^{\mathrm{a}}$ & 9.03 & 20.06 & $39.79^{b}$ & $43.68^{b}$ \\
\hline Mean & 7.04 & 19.18 & 43.95 & 70.25 & 74.14 & 1.09 & 8.96 & 19.62 & 40.38 & 44.28 \\
\hline SE & 0.89 & 1.93 & 4.39 & 6.60 & 8.78 & 0.19 & 0.40 & 1.80 & 1.41 & 0.89 \\
\hline CV & 12.65 & 10.08 & 9.99 & 9.39 & 11.84 & 17.47 & 4.50 & 9.18 & 3.49 & 2.01 \\
\hline$P$ value (species) & 0.113 & 0.256 & 0.514 & 0.009 & 0.527 & 0.045 & 0.29 & 0.154 & 0.018 & 0.0003 \\
\hline
\end{tabular}

SE standard error, CV coefficient of variation

a,b Species means with different letters in column are significantly different

80th, and the 100th days of harvest, but the values for the 40th and the 60th days were found to be similar.

The current result also indicated higher DM accumulation for $V$. villosa than $V$. dasycarpa at the 80th and 100th sampling days. In the current study, similar plant height values were observed at the different cutting times for both vetch species except the 80th day at which $V$. dasycarpa gave higher values than $V$. villosa (Table 5).

The possible reason for higher DM accumulation for $V$. villosa than $V$. dasycarpa might be due to the higher branching abilities observed in $V$. villosa compared to $V$. dasycarpa. This result was in line with Gezahegn et al. [19] who obtained similar results among the vetch species during the initial growth stage.

\section{Dry matter yield of oat and vetch mixtures}

The dry matter yield (DMY) of mixtures were significantly $(P<0.001)$ affected both by main effects and their interactions (Table 6). Dry matter yield was higher at $\mathrm{HS}_{2}(4.99 \mathrm{t} / \mathrm{ha})$, whereas the lowest dry matter yield (3.42 t/ha) was obtained at $\mathrm{HS}_{1}$. The lower DMY at $\mathrm{HS}_{1}$ for mixtures could be due to lower DM accumulation
Table 6 Dry matter yield (t/ha) of oats-vetch mixtures at different harvesting

\begin{tabular}{lllll}
\hline Oats-vetch mixtures & \multicolumn{4}{l}{ Harvesting stages } \\
\cline { 2 - 5 } & $\mathrm{HS}_{\mathbf{1}}$ & $\mathrm{HS}_{\mathbf{2}}$ & $\mathbf{H S}_{\mathbf{3}}$ & Mean \\
\hline Oats Cl-8237 + Vicia villosa $\left(\mathrm{O}_{1} \mathrm{~V}_{1}\right)$ & $3.99^{\mathrm{d}}$ & $6.16^{\mathrm{a}}$ & $5.11^{\mathrm{b}}$ & $5.09^{\mathrm{a}}$ \\
Oats Cl-8237+Vicia dasycarpa $\left(\mathrm{O}_{1} \mathrm{~V}_{2}\right)$ & $3.73^{\mathrm{d}}$ & $5.32^{\mathrm{b}}$ & $4.46^{\mathrm{c}}$ & $4.5^{\mathrm{b}}$ \\
Oats Cl-8251 + Vicia villosa $\left(\mathrm{O}_{2} \mathrm{~V}_{1}\right)$ & $3.18^{\mathrm{e}}$ & $4.54^{\mathrm{c}}$ & $3.27^{\mathrm{e}}$ & $3.66^{\mathrm{c}}$ \\
Oats Cl-8251 + Vicia dasycarpa $\left(\mathrm{O}_{2} \mathrm{~V}_{2}\right)$ & $2.76^{\mathrm{f}}$ & $3.93^{\mathrm{d}}$ & $2.99^{\mathrm{ef}}$ & $3.22^{\mathrm{d}}$ \\
Mean & $3.42^{\mathrm{c}}$ & $4.99^{\mathrm{a}}$ & $3.96^{\mathrm{b}}$ & 4.12 \\
SE & 0.1599 & & & \\
CV & 3.882 & & & \\
P value (mixtures) & 0.0001 & & & \\
\hline
\end{tabular}

SE standard error, $C V$ coefficient of variation, $H S$ harvesting stage

a-f Mean values with different superscripts across a row and across a column are significantly different $(P<0.001)$

per plant which is expected at early stage of growth. The reason for highest DMY at $\mathrm{HS}_{2}$ could be due to the highest tiller number, leaf formation, leaf elongation, stem development and the maximum plant vegetative growth attended at this stage. The current result was conformed 
to McDonald et al. [22] who stated that stage of maturity of forages at harvesting stage is the most important factor that influences the DMY and nutritional quality. However, the current result was lower than the findings of Berhanu et al. [18] who obtained the lowest total herbage yield (4.1 t/ha) at $\mathrm{HS}_{1}$ and increased with increase in harvesting days under rain fed condition. Different scholars [23-25] reported different results with the current study indicating an increase in DM yield with delayed cutting time. The variation observed between the current study and the earlier works might be due to climatic, season and location differences which could affect the performance of different plant species differently.

When the values of mixture are considered, higher mean DMY (5.09 $\mathrm{t} / \mathrm{ha}$ ) was obtained in the mixture of CI-8237 $+V$. villosa followed by CI-8237 $+V$. dasycarpa (4.5 t/ha) and CI-8251+V. villosa (3.66 t/ha), respectively, whereas the lowest mean DMY (3.22 t/ ha) was recorded in the mixture of CI-8251+V. dasycarpa (Table 6). In the present study, those varieties with higher dry matter accumulation and morphological performance in the growing period gave better DM yield. Hence, better plant vigor tended to produce higher herbage yield as compared to less vigorous varieties.

In case of interaction effect, the highest DMY $(6.16 \mathrm{t} /$ ha) was recorded for CI-8237 $+V$. villosa mixtures at $\mathrm{HS}_{2}$ (Table 6). The lowest DMY (2.76 t/ha) was obtained from CI-8251 $+V$. dasycarpa mixtures at $\mathrm{HS}_{1}$ and HS3. The results of the current study were supported by Gezahegn et al. [19] who reported that DMY is affected by genetic and environmental conditions at different forage harvesting stages. This result was also in line with the reports of Desalegn and Hassen [20] who obtained the highest dry matter yield of $3.64 \mathrm{t} /$ ha from $V$. villosa which was found to be the best adaptive vetch species among the four vetch species tested by the author. Other studies by Bimrew et al. [26] and Genet et al. [27] showed that the dry matter yield was increased with an increase in harvesting days in Desho grass.

\section{Nutritional quality of oat and vetch mixtures Crude protein contents of oat-vetch mixtures at different harvesting stages}

The mean crude protein content was significantly $(P<0.001)$ affected by harvesting stages and the interaction effects $(P<0.05)$. However, there were no significant differences $(P>0.05)$ among oat-vetch mixtures. Higher $(P<0.001)$ crude protein percent was obtained at $\mathrm{HS}_{1}$ and lower $(P<0.001)$ value at $\mathrm{HS}_{3}($ Table 7$)$. The possible reason for higher $\mathrm{CP}$ content at $\mathrm{HS}_{1}$ could be plants accumulated higher amounts of $\mathrm{CP}$ at early stages of growth and declines due to the dilution of the CP content by an increase in structural carbohydrate as plants advanced in
Table 7 Crude protein content (\%) of oats-vetch mixtures at different harvesting stage

\begin{tabular}{lllll}
\hline Oats-vetch mixtures & \multicolumn{4}{l}{ Harvesting stages } \\
\cline { 2 - 5 } & $\mathbf{H S}_{\mathbf{1}}$ & $\mathbf{H S}_{\mathbf{2}}$ & $\mathbf{H S}_{\mathbf{3}}$ & Mean \\
\hline Oats Cl-8237+Vicia villosa $\left(\mathrm{O}_{1} \mathrm{~V}_{1}\right)$ & $20.10^{\mathrm{a}}$ & $15.03^{\mathrm{cd}}$ & $15.59^{\mathrm{cd}}$ & 16.91 \\
Oats Cl-8237+Vicia dasycarpa & $17.15^{\mathrm{bc}}$ & $17.07^{\mathrm{bc}}$ & $16.12^{\mathrm{cd}}$ & 16.78 \\
$\left(\mathrm{O}_{1} \mathrm{~V}_{2}\right)$ & & & & \\
Oats Cl-8251+Vicia villosa $\left(\mathrm{O}_{2} \mathrm{~V}_{1}\right)$ & $19.55^{\mathrm{ab}}$ & $16.81^{\mathrm{bcd}}$ & $15.20^{\mathrm{cd}}$ & 17.19 \\
Oats Cl-8251+Vicia dasycarpa & $21.38^{\mathrm{a}}$ & $16.03^{\mathrm{cd}}$ & $13.97^{\mathrm{d}}$ & 17.13 \\
$\quad\left(\mathrm{O}_{2} \mathrm{~V}_{2}\right)$ & & & & \\
Mean & $19.54^{\mathrm{a}}$ & $16.24^{\mathrm{b}}$ & $15.22^{\mathrm{b}}$ & 17.00 \\
$\mathrm{SE}$ & 1.56 & & & \\
CV & 9.20 & & & \\
$P$ value (mixtures) & 0.9400 & & & \\
\hline
\end{tabular}

SE standard error, CV coefficient of variation, HS harvesting stage

a-d Mean values with different superscripts across a row is significantly different $(P<0.001)$

age. On the other hand, the lowest $\mathrm{CP}$ recorded at $\mathrm{HS}_{3}$ might be the reduction of leaves due to shattering of leaves in vetch species.

The current result of crude protein percent is in line with Berhanu et al. [18] who reported a decreasing trend in crude protein with increase in harvesting stages in oat and vetch mixtures. Similarly, Dura et al. [28] reported higher $\mathrm{CP}$ contents in purely sown legumes than in cereals. Scholars $[26,27]$ also reported that in Desho grass, the $\mathrm{CP}$ content was decreased as the age of plants advanced. In case of interaction effect, the highest $\mathrm{CP}$ (21.38\%) was obtained from the mixture of CI-8251 $+V$. dasycarpa at $\mathrm{HS}_{1}$. The high $\mathrm{CP}$ value obtained in mixed forages of the current study is supported by Berhanu et al. [18] who reported that mixtures of forage up to $25-50 \%$ legume produced more quality forage and yield per unit area than purely sown forages. Befekadu and Yunus [29] suggested that the maximum CP concentration was recorded in the highest proportion of legume plants and Fantahun [30] also reported that the highest quality forage obtained from oat with legume mixtures. Gezahegn [31] reported 18\% CP in oats-vetch mixture, and Starks et al. [32] reported 26\% CP in case of pure stand vetch.

\section{Crude protein yield of oat and vetch mixtures}

Crude protein yield was affected $(P<0.001)$ by harvesting stages, mixtures and their interactions (Table 8).

The highest mean crude protein yield $(0.81 \mathrm{t} / \mathrm{ha})$ was recorded at $\mathrm{HS}_{2}$ followed by $\mathrm{HS}_{1}(0.66 \mathrm{t} / \mathrm{ha})$ and the least $\left(0.61 \mathrm{t} / \mathrm{ha}\right.$ ) was obtained at $\mathrm{HS}_{3}$ (Table 8). In the current study, the low $\mathrm{CP}$ yield recorded at later harvesting ages might be due to the differences in varieties (oat and 
Table 8 Crude protein yield ( $t / h a)$ for oat-vetch mixtures at different harvesting stages

\begin{tabular}{lllll}
\hline Oats-vetch mixtures & \multicolumn{4}{l}{ Harvesting stages } \\
\cline { 2 - 5 } & $\mathbf{H S}_{\mathbf{1}}$ & $\mathbf{H S}_{\mathbf{2}}$ & $\mathbf{H S}_{\mathbf{3}}$ & Mean \\
\hline Oats Cl-8237+ Vicia villosa $\left(\mathrm{O}_{1} \mathrm{~V}_{1}\right)$ & $0.79^{\mathrm{b}}$ & $0.92^{\mathrm{a}}$ & $0.79^{\mathrm{b}}$ & $0.84^{\mathrm{a}}$ \\
Oats Cl-8237+Vicia dasycarpa $\left(\mathrm{O}_{1} \mathrm{~V}_{2}\right)$ & $0.64^{\mathrm{cd}}$ & $0.91^{\mathrm{a}}$ & $0.72^{\mathrm{bc}}$ & $0.75^{\mathrm{b}}$ \\
Oats $\mathrm{Cl}-8251+$ Vicia villosa $\left(\mathrm{O}_{2} \mathrm{~V}_{1}\right)$ & $0.62^{\mathrm{cd}}$ & $0.76^{\mathrm{b}}$ & $0.49^{\mathrm{ef}}$ & $0.63^{\mathrm{c}}$ \\
Oats Cl-8251+Vicia dasycarpa $\left(\mathrm{O}_{2} \mathrm{~V}_{2}\right)$ & $0.59^{\mathrm{de}}$ & $0.63^{\mathrm{cd}}$ & $0.42^{\mathrm{f}}$ & $0.54^{\mathrm{d}}$ \\
Mean & $0.66^{\mathrm{b}}$ & $0.81^{\mathrm{a}}$ & $0.61^{\mathrm{c}}$ & 0.69 \\
$\mathrm{SE}$ & 0.058 & & & \\
$\mathrm{CV}$ & 8.91 & & & \\
$P$ value (mixtures) & 0.0001 & & &
\end{tabular}

$S E$ standard error, $C V$ coefficient of variation, $H S$ harvesting stage

a-f Mean values with different superscripts across a row and across a column are significantly different $(P<0.001)$

vetch) as well as the loss of leaves and the increment of the cell wall constituents which negatively affect crude protein yield. Geleti [33] suggested that CPY is the product of total dry matter yield and CP concentration in the plant which can be substantiated by the values obtained from $\mathrm{CP}$ percent and the dry mater yield obtained from each treatment in Tables 6 and 7. Because of this fact, the amount of $\mathrm{CPY}$ was reduced at $\mathrm{HS}_{3}$. The crude protein yield $(\mathrm{CPY})$ showed significance difference $(\mathrm{P}<0.001)$ among treatments with the highest $\mathrm{CPY}$ obtained from CI-8237 $+V$. villosa and the least recorded from CI-8251+V. dasycarpa (Table 8). The current result agrees with Diriba and Vaars [34] who suggested higher CPY being an indicative of importance of the forages. Gezahegn [31] also stated genetic characteristics being the basis for variation in nutritive values that determine production, utilization and the various management practices.

\section{Total ash content of oats/vetch mixtures}

Total ash content was significantly affected $(P<0.001)$ by harvesting stages (Table 9). However, there was no any significant difference $(P>0.05)$ among the treatment mixtures as well as their interaction. Significantly higher $(P<0.001)$ ash content was recorded at $\mathrm{HS}_{1}$. A reducing trend in ash content was recorded from $\mathrm{HS}_{1}$ to $\mathrm{HS}_{3}$. However, $\mathrm{HS}_{2}$ and $\mathrm{HS}_{3}$ were not statistically different from each other.

The ash content obtained in this study was in agreement with Diriba and Vaars [34] who reported that mineral contents of plants declined during the maturing process due to natural dilution and translocation of nutrients from vegetative part to the root system. McDonald et al. [22] also reported that mineral concentration
Table 9 Ash content (\%) of oats-vetch mixtures at different harvesting stages

\begin{tabular}{lllll}
\hline Oats-vetch mixtures & \multicolumn{3}{l}{ Harvesting stages } & \\
\cline { 2 - 5 } & $\mathbf{H S}_{\mathbf{1}}$ & $\mathbf{H S}_{\mathbf{2}}$ & $\mathbf{H S}_{\mathbf{3}}$ & Mean \\
\hline Oats Cl-8237+Vicia villosa $\left(\mathrm{O}_{1} \mathrm{~V}_{1}\right)$ & $12.25^{\mathrm{a}}$ & $10.97^{\text {cde }}$ & $11.18^{\mathrm{bcd}}$ & 11.47 \\
Oats Cl-8237+Vicia dasycarpa & $11.75^{\mathrm{abc}}$ & $10.89^{\text {cde }}$ & $10.37^{\mathrm{de}}$ & 11.00 \\
$\left(\mathrm{O}_{1} \mathrm{~V}_{2}\right)$ & & & & \\
Oats Cl-8251+Vicia villosa $\left(\mathrm{O}_{2} \mathrm{~V}_{1}\right)$ & $12.24^{\mathrm{a}}$ & $11.17^{\mathrm{bcd}}$ & $10.97^{\mathrm{cde}}$ & 11.46 \\
Oats Cl-8251+Vicia dasycarpa & $11.90^{\mathrm{ab}}$ & $11.02^{\mathrm{bcde}}$ & $10.23^{\mathrm{e}}$ & 11.05 \\
$\left(\mathrm{O}_{2} \mathrm{~V}_{2}\right)$ & & & & \\
Mean & $12.03^{\mathrm{a}}$ & $11.02^{\mathrm{b}}$ & $10.69^{\mathrm{b}}$ & 11.25 \\
$\mathrm{SE}$ & 0.47 & & & \\
CV & 4.19 & & & \\
$P$ value (mixtures) & 0.078 & & & \\
\hline
\end{tabular}

SE standard error, CV coefficient of variation, HS harvesting stage

a-e Mean values with different superscripts across a row is significantly different $(P<0.001)$

declines with age and influenced by soil type, soil nutrient levels and seasonal conditions. However, the results of the current study disagree with the results of Yehalem [35] who reported an increase in total ash contents with advancing plant maturity. In general, variation in concentration of minerals in forages can be induced by factors like varieties, plant developmental stage, morphological fractions, climatic conditions, soil characteristics and fertilization regime $[19,36]$.

\section{Fiber and lignin contents Neutral detergent fiber content}

Neutral detergent fiber (NDF) content was affected $(P<0.001)$ both by main effects and their interactions (Table 10). The highest NDF content (54.89\%) was recorded at $\mathrm{HS}_{3}$ and the lowest value (45.98\%) at $\mathrm{HS}_{1}$. The result showed that the NDF content was increased with delayed harvesting stage from $\mathrm{HS}_{1}$ to $\mathrm{HS}_{3}$.

This increase in NDF content with advancing maturity was also reported by other authors $[17,26,35,37$, 38]. This might be due to an increase in fiber content which could be accompanied by a decrease in CP content associated with an increase in the proportion of lignified structural tissue at later stage of growth. The highest NDF was recorded from the mixture of CI-8237 $+V$. villosa, but the values for CI-8237 $+V$. dasycarpa $\left(\mathrm{O}_{1} \mathrm{~V}_{2}\right)$, CI-8251 + V. villosa $\left(\mathrm{O}_{2} \mathrm{~V}_{1}\right)$ and CI-8251 $+V$. dasycarpa $\left(\mathrm{O}_{2} \mathrm{~V}_{2}\right)$ were statistically similar (Table 10). The significant NDF value in one mixture could be due to the genetic make-up of the mixture varieties. 
Table 10 Neutral detergent fiber content (\%) of oatsvetch mixtures at different harvesting stages

\begin{tabular}{lllll}
\hline Oats-vetch mixtures & \multicolumn{4}{l}{ Harvesting stages } \\
\cline { 2 - 5 } & $\mathbf{H S}_{\mathbf{1}}$ & $\mathbf{H S}_{\mathbf{2}}$ & $\mathbf{H S}_{\mathbf{3}}$ & Mean \\
\hline Oats Cl-8237+Vicia villosa $\left(\mathrm{O}_{1} \mathrm{~V}_{1}\right)$ & $46.58^{\mathrm{e}}$ & $52.80^{\mathrm{bc}}$ & $57.09^{\mathrm{a}}$ & $52.16^{\mathrm{a}}$ \\
Oats $\mathrm{Cl}-8237$ + Vicia dasycarpa $\left(\mathrm{O}_{1} \mathrm{~V}_{2}\right)$ & $45.85^{\mathrm{e}}$ & $48.85^{\mathrm{d}}$ & $54.73^{\mathrm{b}}$ & $49.81^{\mathrm{b}}$ \\
Oats $\mathrm{Cl}-8251+$ Vicia villosa $\left(\mathrm{O}_{2} \mathrm{~V}_{1}\right)$ & $45.50^{\mathrm{e}}$ & $49.12^{\mathrm{d}}$ & $54.28^{\mathrm{b}}$ & $49.63^{\mathrm{b}}$ \\
Oats Cl-8251+Vicia dasycarpa $\left(\mathrm{O}_{2} \mathrm{~V}_{2}\right)$ & $45.95^{\mathrm{e}}$ & $51.72^{\mathrm{c}}$ & $53.45^{\mathrm{bc}}$ & $50.38^{\mathrm{b}}$ \\
Mean & $45.98^{\mathrm{c}}$ & $50.63^{\mathrm{b}}$ & $54.89^{\mathrm{a}}$ & 50.49 \\
$\mathrm{SE}$ & 1.18 & & & \\
$\mathrm{CV}$ & 2.34 & & & \\
$P$ value (mixtures) & 0.0006 & & \\
\hline
\end{tabular}

SE standard error, $C V$ coefficient of variation, $H S$ harvesting stage

a-e Mean values with different superscripts across a row and across a column are significantly different $(P<0.001)$

Table 11 Acid detergent fiber content (\%) oats-vetch mixtures at different harvesting stages

\begin{tabular}{lllll}
\hline Oat-vetch mixtures & \multicolumn{4}{l}{ Harvesting stages } \\
\cline { 2 - 5 } & HS $_{\mathbf{1}}$ & HS $_{\mathbf{2}}$ & HS $_{\mathbf{3}}$ & Mean \\
\hline Oats $\mathrm{Cl}-8237+$ Vicia villosa $\left(\mathrm{O}_{1} \mathrm{~V}_{1}\right)$ & $32.43^{\mathrm{f}}$ & $37.24^{\mathrm{bcd}}$ & $39.14^{\mathrm{ab}}$ & $36.27^{\mathrm{ab}}$ \\
Oats $\mathrm{Cl}-8237+$ Vicia dasycarpa & $33.09^{\mathrm{ef}}$ & $35.69^{\mathrm{cd}}$ & $37.62^{\mathrm{bc}}$ & $35.47^{\mathrm{b}}$ \\
$\left(\mathrm{O}_{1} \mathrm{~V}_{2}\right)$ & & & & \\
Oats $\mathrm{Cl}-8251+$ Vicia villosa $\left(\mathrm{O}_{2} \mathrm{~V}_{1}\right)$ & $32.92^{\text {ef }}$ & $35.29^{\text {cde }}$ & $37.69^{\mathrm{bc}}$ & $35.30^{\mathrm{b}}$ \\
Oats $\mathrm{Cl}-8251+$ Vicia dasycarpa & $35.03^{\mathrm{de}}$ & $37.11^{\mathrm{bcd}}$ & $40.43^{\mathrm{a}}$ & $37.52^{\mathrm{a}}$ \\
$\left(\mathrm{O}_{2} \mathrm{~V}_{2}\right)$ & $33.37^{\mathrm{c}}$ & $36.33^{\mathrm{b}}$ & $38.72^{\mathrm{a}}$ & 36.14 \\
Mean & 1.35 & & & \\
SE & 3.73 & & & \\
CV & 0.0079 & & & \\
$P$ value (mixtures) & & & & \\
\hline
\end{tabular}

SE standard error, $C V$ coefficient of variation, $H S$ harvesting stage

a-f Mean values with different superscripts across a row and across a column are significantly different $(P<0.01)$

\section{Acid detergent fiber content}

Acid detergent fiber was significantly affected $(P<0.001)$ by harvesting stages and $(P<0.01)$ due to mixtures, but not their interactions (Table 11).

Based on this result, treatments harvested at $\mathrm{HS}_{3}$ gave the highest ADF content (38.72\%) compared to the rest of the harvesting stages $\left(\mathrm{HS}_{2}\right.$ and $\mathrm{HS}_{3}$ ) with the lowest mean NDF value $(33.37 \%)$ recorded at $\mathrm{HS}_{1}$ (Table 11). This result shows that ADF content was increased with advancing maturity. The ADF value in the current study was in line with the findings of Berhanu et al. [18] who reported $40.68 \%$ NDF value ranging from 33.09 to 44.97 at different harvesting days in case of oat and vetch mixtures. The highest ADF concentration produced at late harvesting stage might
Table 12 Acid detergent lignin content (\%) of oats-vetch mixtures at different harvesting stages

\begin{tabular}{lcccc}
\hline Oats-vetch mixtures & \multicolumn{4}{l}{ Harvesting stages } \\
\cline { 2 - 5 } & HS $_{\mathbf{1}}$ & HS $_{\mathbf{2}}$ & $\mathbf{H S}_{\mathbf{3}}$ & Mean \\
\hline Oats Cl-8237+ Vicia villosa $\left(\mathrm{O}_{1} \mathrm{~V}_{1}\right)$ & $7.18^{\mathrm{f}}$ & $11.15^{\mathrm{abc}}$ & $12.01^{\mathrm{ab}}$ & 10.11 \\
Oats $\mathrm{Cl}-8237+$ Vicia dasycarpa & $8.81^{\text {def }}$ & $9.66^{\mathrm{cde}}$ & $11.40^{\mathrm{abc}}$ & 9.96 \\
$\left(\mathrm{O}_{1} \mathrm{~V}_{2}\right)$ & & & & \\
Oats Cl-8251+Vicia villosa $\left(\mathrm{O}_{2} \mathrm{~V}_{1}\right)$ & $7.53^{\mathrm{ef}}$ & $9.52^{\text {cde }}$ & $11.17^{\mathrm{abc}}$ & 9.41 \\
Oats Cl-8251+Vicia dasycarpa & $8.14^{\mathrm{ef}}$ & $10.46^{\mathrm{bcd}}$ & $12.88^{\mathrm{a}}$ & 10.49 \\
$\left(\mathrm{O}_{2} \mathrm{~V}_{2}\right)$ & & & & \\
Mean & $7.92^{\mathrm{c}}$ & $10.20^{\mathrm{b}}$ & $11.87^{\mathrm{a}}$ & 9.99 \\
$\mathrm{SE}$ & 1.14 & & & \\
$\mathrm{CV}$ & 11.46 & & & \\
$P$ value (mixtures) & 0.2712 & & & \\
\hline
\end{tabular}

SE standard error, $C V$ coefficient of variation, $H S$ harvesting stage

a-f Mean values with different superscripts across a row is significantly different $(P<0.001)$

be due to the decrease in leaf to stem proportion and an increase in cell wall lignifications which may lead to raised ADF concentration at an advanced growth stage. Likewise, Bimrew et al. [26] and Cetin and Turk [38] reported that the highest ADF value was recorded at late harvesting period. On the other hand, in the current study, the highest ADF value was recorded for CI-8251 + V. dasycarpa, but CI-8237 + V. villosa gave statistically similar values.

\section{Acid detergent lignin content}

Acid detergent lignin (ADL) was significantly $(P<0.001)$ affected by harvesting stages, but mixtures and their interactions did not show significant effect on this parameter (Table 12). The highest (11.87\%) and lowest (7.92\%) mean ADL contents were recorded at $\mathrm{HS}_{3}$ and $\mathrm{HS}_{1}$, respectively.

Generally, the current result showed that ADL content was increased with advancing maturity. This could be due to rapid lignifications as the result of concentration of structural carbohydrates at advanced age of plant growth. The present result was in line with other findings which reported higher lignin contents with prolonged growth stages [22, 27, 39].

\section{Conclusions}

Based on the current result, all agronomic parameters, biomass yield and nutritional value were affected by harvesting stages. The different oats varieties and vetch species in this study also showed variations in most measured traits due to differences in genetic, seasonal 
and environmental factors. Plant height, leaf number and leaf to stem ratio were recorded to be higher for oats CI-8237 resulting in higher dry matter accumulation rate over the growing period. In case of vetch species, a higher number of branches were recorded in $V$. villosa compared to $V$. dasycarpa, whereas higher plant height was recorded in $V$. dasycarpa. Therefore, CI-8237 and $V$. villosa combination performed better in most agronomic and nutritional parameters at harvesting stage two (milk stage) and it is recommended for fodder production in similar agro-ecology using the residual moisture to fill the dry season feed shortage (through conserved forage) and improve livestock productivity and enhance food security.

\section{Abbreviations}

ADF: acid detergent fiber; ADL: acid detergent lignin; AOAC: association of Official Analytical Chemists; CP: crude protein; CPY: crude protein yield; CSA: central Statistical Agency; CV: coefficient of variation; DM: dry matter; GLM: general linear model; HS: harvesting stage; NDF: neutral detergent fiber; RCBD: randomized complete block design; SAS: statistical analysis system.

\section{Authors' contributions}

EA contributed in research proposal writing, data collection, data analysis, data interpretation and article writing. BA contributed in research proposal writing and article writing. YM contributed in research proposal and article writing. All authors read and approved the final manuscript.

\section{Authors' information}

Eshet is M.Sc. holder in animal nutrition and feed processing, currently working in Tach Gaynt district of Trade and Industry Office. Berhanu an Assistant Professor of Animal Feeds and Nutrition, currently teaching and conducting research in the area of animal feeds and feeding, animal production and productivity improvement in Ethiopia. Yeshambel is an Associate Professor of Animal Feeds and Nutrition, currently teaching and conducting research in the area of animal feeds and feeding, animal production and productivity improvement in Ethiopia.

\section{Author details}

${ }^{1}$ Department of Animal Science, College of Agricultural and Natural Resource, Debre Markos University, P.O. Box 269, Debre Markos, Ethiopia. ${ }^{2}$ Department of Animal Production and Technology, Bahir Dar University, P.O. Box 5501, Bahir Dar, Ethiopia.

\section{Acknowledgements}

The first author acknowledges Holeta Agriculture Research center and Debre Berhan Research Center for their support in the analysis of the feed chemical composition analysis.

\section{Competing interests}

The authors declare that they have no competing interests.

\section{Availability of supporting data}

The datasets used and/or analyzed during the current study available from the corresponding author on reasonable request.

\section{Consent for publication}

Not applicable.

\section{Ethical approval and consent to participate}

Not applicable.

\section{Funding}

Tach Gaynt District of Trade Industry Office, North Gondar Zone.

\section{Publisher's Note}

Springer Nature remains neutral with regard to jurisdictional claims in published maps and institutional affiliations.

Received: 31 March 2018 Accepted: 26 November 2018

Published online: 04 December 2018

\section{References}

1. CSA. Agricultural sample survey volume II: report on livestock and livestock characteristics (Private peasant holdings). Central Statistics Authority (CSA), Statistical Bulletin 583. Addis Ababa, Ethiopia. 2016.

2. Asresie A, Zemedu L. Contribution of livestock sector in ethiopian economy: a review. Adv Life Sci Technol. 2015:29:79-91.

3. Alemayehu M, Getnet A. The evaluation of forage seed production in Ethiopia. In: Assefa G, Dejene M, Hanson J, Anemut G, Mengistu S, Mengistu $A$, editors. Forage seed research and development in Ethiopia. Addis Ababa: Ethiopia Institute of Agricultural Research; 2012. p. 15-32.

4. Menale K. Economic and environmental benefits of forage legume cereal intercropping in the mixed farming system: a case study in West Gojam, Ethiopia. 2011. http://www.edri.org.et/Resources/Working_Papers/ ED.of_Forage_Legume.pdf.

5. Nadeem M, Ansar M, Anwar A, Hussain A, Khan S. Performance of winter cereal-legumes fodder mixtures and their pure stand at different growth stages under rainfed conditions of Pothowar. J Agric Res. 2010;48:181-91.

6. Matt A, Geoffrey B, Robert S, Leah R. Grass-legume proportions in forage seed mixtures and effects on herbage yield and weed abundance. Agron J. 2013;105:1-67.

7. Erol A, Kaplan M, Kizilsimsek M. Oats (Avena sativa): common vetch (Vicia sativa) mixtures grown on a low-input basis for a sustainable agriculture. Trop Grassl. 2009;43:191-6.

8. Getnet A, Tekleyohanes B, Lemma G, Mesfin D, Diriba G. Major herbaceous forage legumes: some achievements in species and varietal evaluation in Ethiopia. In: Kemal A, Seid A, Surendra B, Gemechu K, Rajendra $M$, Khaled $M$, editors. Food and forage legumes of Ethiopia: progress and prospects. Proceedings of the work shop on food and forage legumes, 22-26 September 2003, Addis Ababa, Ethiopia. 2003.

9. Mengistu S. Forage development for sheep and goats. Sheep and goat production handbook for Ethiopia. Ethiopia Sheep and Goat Productivity Improvement Program. 2008.

10. IPMS (Improving Productivity and Market Success of Ethiopian Farmers). IPMS ATLAS 2008, Fogera woreda. 2008.

11. Fogera Agricultural and Natural Resource Office (FANRO). Annual statistical data of planning and monitoring team, Fogera. 2016.

12. Akililu M, Alemayehu M. Measurements in pasture and forage cropping systems. Technical manual 18, EIAR, Addis Ababa, Ethiopia. 2007; p. 41

13. Getnet A. Feed resource assessment and evaluation of forage yield, quality and intake of oats and vetches grown in pure stand and mixtures in the highlands of Ethiopia. M.Sc. thesis, Uppsala. 1999; p. 1-26.

14. AOAC (Association of Official Analytical Chemists). Official methods of analysis. 15th ed. USA. 1990.

15. Van Soest PJ, Robertson JB, Lewis BA. Meal on performance and carcass characteristics of methods for dietary fiber, neutral detergent fiber and finishing Awassi lambs. Trop Anim Health Prod. 1991;42:293-300.

16. SAS (Statistical Analysis Software). Statistical analysis for science, software release 9.1. Cary: SAS Institute Inc.; 2008.

17. Shoaib M, Ayub M, Zamir M, Akhtar MJ. Dry matter yield of oat-Egyptian clover mixture under varying proportions and different growth stages of oat. Int J Agric Biol. 2013;15(4):673-9.

18. Berhanu A, Melaku S, Prasad NK. Effects of varying seed proportions and harvesting stages on biological compatibility and forage yield of oats (Avena sativa L.) and vetch (Vicia villosa R.) mixtures. Livestock Research for Rural Development. 2007; 19:12. Retrieved August 24, 2017, from http://www.Irrd.org/Irrd19/1/alem19012.htm.

19. Gezahegn K, Getnet A, Alemayehu M, Fekede F. Forage nutritive values of vetch species and their accessions grown under nitosol and vertisol conditions in the central highlands of Ethiopia. Livestock research for rural development. 2013; 26. Retrieved November 10, 2016, from http:// www.Irrd.org/lrrd26/1/kebe26020.htm. 
20. Desalegn $\mathrm{K}$, Wasihun $\mathrm{H}$. Evaluation of biomass yield and nutritional value of different species of vetch (Vicia). Acad J Nutr. 2015;4(3):99-105. https:// doi.org/10.5829/idosi.ajn.2015.4.3.96130.

21. Negash D, Animut G, Urgie M, Mengistu S. Evaluation of forage yield and soil characterization of oats (Avena sativa) grown in mixture with vetch (Vicia villosa) with or without phosphorus fertilization in East shoa Zone, Ethiopia. Acad Res J Agric Sci Res. 2017;5(3):219-29. https://doi. org/10.14662/ARJASR2017.022

22. McDonald P, Edward RA, Greenhalgh JFD, Morgan GA. Animal nutrition. 6th ed. Pearson Educational Limited: Edinburgh; 2002. p. 544.

23. Ayub M, Tanveer A, Nadeem MA, Tahir M, Ibrahim M. Effect of seed proportion and nitrogen application on forage yield and nutritive value of barley-pea mixture harvested at different times. Pak J Life Soc Sci. 2008;6(2):135-9.

24. Ammar H, Lopez S, Andres S. Influence of maturity stage of forage grasses and leguminous on their chemical composition and in vitro dry matter digestibility. Options Mediterr. 2010;92:199-203.

25. Atis I, Konuskan O, Duru M, Gozubenli H, Yilmaz S. Effect of harvesting time on yield, composition and forage quality of some forage sorghum cultivars. Int J Agric Biol. 2012;14:879-86.

26. Bimrew A, Solomon D, Taye T, Firew $T$, Jane W. Effects of altitude and harvesting days on morphological characteristics, yield and nutritive value of desho grass (Pennisetum pedicellatum) in Ethiopia. Ph.D. dissertation of Jima University, 2016.

27. Genet T, Bimrew A, Yeshambel M. Effects of harvesting age and spacing on plant characteristics, chemical composition and yield of desho grass (Pennisetum pedicellatum Trin.) in the highlands of Ethiopia. Trop Grassl. 2017;5(2):77-84.

28. Dura K, Aleksandar M, Branko M, Sanja V, Nenad D. Common vetchwheat intercropping: haylage yield and quality depending on sowing rates. Afr J Biotechnol. 2012:11(30):7637-42.

29. Befekadu C, Yunus A. Evaluation of biomass yield and growth performance of alfalfa and oat cultivars in the High Land of Arsi, Ethiopia. Livestock Research for Rural Development. 2015; 27: Article \#114. Retrieved January 2018, from http://www.Irrd.org/Irrd27/6/befe27114.html.
30. Fantahun D. The effect of variety and seed proportions on yield, nutritional quality and compatibility of oats and vetch mixtures. M.Sc. thesis, Addis Ababa University, College of Veterinary Medicine and Agriculture, Ethiopia. 2016.

31. Gezahegn K. Evaluation of vetch species for yield, yield components and herbage quality in the central highlands of Ethiopia. Acad Res J Agric Sci Res. 2016;4:264-78. https://doi.org/10.14662/ARJASR2016.034.

32. Starks PJ, Zhao D, Philips WA, Coleman SW. Herbage mass, nutritive value and canopy spectral reflectance of Bermuda grass. Grass Forage Sci. 2006:61:101111.

33. Geleti D. Agronomic and nutritional evaluation of selected forage legumes and locally available feedstuff, and characterization of forage and dairy innovation systems in Bako and Nekemte Peri-Urban Areas, Oromia, Ethiopia. Ph.D. dissertation, Addis Ababa University, Ethiopia. 2014.

34. Diriba G, Vaars R. Productivity of panicum coloratum under varying stages of harvest, low level of nitrogen fertilizer and in combination with stylosanthes during establishment year. M.Sc. thesis, Alemaya University, Ethiopia. 2000.

35. Yehalem D. Effect of stage of harvesting on botanical composition of selected natural pasture for optimum hay production at Andassa, North Western Ethiopia. M.Sc. thesis, Alemaya University, Ethiopia. 2004; p. 78.

36. Jukenvicius S, Sabiene N. The content of mineral elements in some grasses and legumes. Ekologija. 2007;53:44-52.

37. Kitaba A, Tamir B. Effect of harvesting stage and nutrient levels on nutritive values of natural pasture in central highlands of Ethiopia. Agric Trop Subtrop. 2007;40(1):7-12.

38. Cetin I, Turk M. The effects of different harvest times on forage yield and quality of some vetch (Vicia spp.) species. Suleyman Demirel University, Faculty of Agriculture, Department of Field Crops, Isparta, Turkey, 2016; p. 251-256.

39. Ansah T, Osafo ELK, Hanne HH. Herbage yield and chemical composition of four varieties of Napier (Pennisetum purpureum) grass harvested at three different days after planting. Agric Biol J N Am. 2010;1(5):923-9.
Ready to submit your research? Choose BMC and benefit from:

- fast, convenient online submission

- thorough peer review by experienced researchers in your field

- rapid publication on acceptance

- support for research data, including large and complex data types

- gold Open Access which fosters wider collaboration and increased citations

- maximum visibility for your research: over 100M website views per year

At $\mathrm{BMC}$, research is always in progress.

Learn more biomedcentral.com/submissions 